\title{
Experimental and human studies on antimony metabolism: their relevance for the biological monitoring of workers exposed to inorganic antimony
}

\author{
R Bailly, R Lauwerys, J P Buchet, P Mahieu, J Konings
}

\begin{abstract}
Unlike inorganic arsenic, inorganic trivalent antimony ( $\mathbf{S b}$ ) is not methylated in vivo. It is excreted in the bile after conjugation with glutathione and also in urine. A significant proportion of that excreted in bile undergoes an enterohepatic circulation. In workers exposed to pentavalent $S b$, the urinary $S b$ excretion is related to the intensity of exposure. It has been estimated that after eight hours exposure to $500 \mu \mathrm{g} \mathrm{Sb} / \mathrm{m}^{3}$, the increase of urinary $S b$ concentration at the end of the shift amounts on average to $35 \mu \mathrm{g} / \mathrm{g}$ creatinine.
\end{abstract}

Antimony ( $\mathrm{Sb}$ ) and its compounds are mainly used for the production of alloys, flame retardants, and in the glass industry. Some derivatives are also used in the treatment of tropical diseases. Antimony resembles arsenic in its chemical properties; both belong to the same group (Va) of the periodic table. Knowledge of the metabolism of inorganic Sb in mammals, however, is more limited than that of arsenic. ${ }^{12}$ Studies in animals have suggested that trivalent $\mathrm{Sb}$ is excreted mainly in the faeces and to a lesser extent in urine whereas the reverse holds true for pentavalent $\mathrm{Sb}$. Increased urinary excretion of $\mathrm{Sb}$ has been found in workers exposed to $\mathrm{Sb}_{2} \mathrm{O}_{3}$ in a glass producing factory. ${ }^{3}$

This paper summarises the results of experimental studies designed to assess the handling of inorganic trivalent $\mathrm{Sb}$ in vivo, in particular to determine

\footnotetext{
Industrial Toxicology and Occupational Medicine Unit, Catholic University of Louvain, Clos Chapelleaux-Champs PO Box 30.54, B-1200 Brussels, Belgium

R Bailly, R Lauwerys, J P Buchet

Intensive Care Unit, Cliniques Universitaires St Luc, Catholic University of Louvain, avenue Hippocrate 10, B-1200 Brussels, Belgium

$P$ Mahieu

Medische Dienst, MHO, A Greinerstraat 14, B-2710 Hoboken, Belgium

J Konings
}

whether, like arsenic, trivalent $\mathrm{Sb}$ is methylated, and to identify the best approach for the biological monitoring of workers exposed to $\mathrm{Sb}$. Some aspects of the toxicokinetics of Sb after the voluntary ingestion of a trivalent $\mathrm{Sb}$ salt by a woman and the relation between $\mathrm{Sb}$ excretion in urine and the intensity of occupational exposure to pentavalent $\mathrm{Sb}$ compounds are also reported.

\section{Materials and methods \\ REAGENTS}

Reduced glutathione (GSH), D-L-buthionine-(SR)-sulfoximine (BSO), and cyanocobalamine were obtained from Sigma Chemie GmbH (Deisenhofen, Germany). S-Adenosyl-L-methionine (SAME) (disulphate di-p-toluene-sulphonate salt) was a gift from Bioresearch (Liscate, Italy). Butylated hydroxytoluene (BHT) was purchased from Janssen Chimica (Beerse, Belgium), the ion exchange resin (AG50 W-X8, 100-200 mesh) from Bio-Rad (Brussels, Belgium), and antimony trichloride $\left(\mathrm{SbCl}_{3}\right)$ from Fluka AG (Buchs, Switzerland). Other analytical grade reagents were from Merck (Darmstadt, Germany).

\section{STUDY POPULATION}

A woman (24 years old) was admitted to hospital within one hour of the voluntary ingestion of an unknown quantity of a powder containing $\mathrm{Sb}_{2} \mathrm{~S}_{3}$ for veterinary use. The clinical examination at admission was normal. The patient only complained of slight epigastralgia and dysphagia and a metallic taste in the mouth. A gastric lavage was immediately performed and the subsequent treatment consisted in forced diuresis (10-14 1/24 hours), repeated gastric juice aspiration, bile collection, and antidotal therapy (200 mg dimercaprol three times a day for five days).

The patient did not develop any clinical signs of intoxication and the routine biological tests remained in the normal range. She was discharged on day six. Antimony concentrations were determined in blood, urine, bile, and gastric juice.

Twenty male workers (age range 20 to 54 years) from a non-ferrous smelter producing antimony 
pentoxide and sodium antimoniate volunteered to participate in the study of the relation between airborne $\mathrm{Sb}$ concentration and its concentration in urine. Their duration of exposure to $\mathrm{Sb}$ ranged from 0.5 to 17 years.

\section{AIR SAMPLING}

Breathing zone air was aspirated during one whole shift through a $0.8 \mu \mathrm{m}$ millipore filter, type AAWPO3700 (Molsheim, France) by means of a personal battery operated pump (Casella, type AFC123, London, UK) at a flow rate of $11 /$ minute. The filter was mineralised in $\mathrm{HNO}_{3}$ in the presence of $1 \mathrm{mg} \mathrm{Ni}$; the $\mathrm{Sb}$ concentration was determined by atomic absorption spectrometry.

\section{ANIMALS}

Adult male Sprague Dawley rats (body weight 200$300 \mathrm{~g}$ ) were used. They had free access to water and a standard diet (AO3 pellets UAR, Epinay-sur-Orge, France). The animals were housed in stainless steel cages and maintained in an environment designed for controlled humidity $(50 \%)$, temperature $\left(25^{\circ} \mathrm{C}\right)$, and a 12 hour photocycle. Before tissue collection, rats were anaesthetised with pentobarbital. Blood was sampled by cardiac puncture and after sectioning the inferior vena cava the animals were perfused through a needle introduced in the left ventricle, with $150 \mathrm{ml}$ ice cold $0.9 \%$ sodium chloride containing $1 \mathrm{mM}$ ethylenediaminetetra-acetic acid. Tissues were removed, rinsed in the same medium, blotted on filter paper, and weighed. Catheterisation of bile ducts and postoperative restraint were performed by the methods of Waynforth. ${ }^{4}$

Changes in hepatic GSH concentration were induced either with BHT (a single oral dose of $0.8 \mathrm{~g}$ / $\mathrm{kg} 48$ hours before the challenge dose of $\mathrm{Sb}$ ) or with
BSO $(0.625 \mathrm{~g} / \mathrm{kg}$ intraperitoneally two hours before and 12 and 30 hours after the challenge dose of $\mathrm{Sb}$ ). Solutions of $\mathrm{SbCl}_{3}$ were prepared in $1 \%$ tartaric acid and $0.9 \%$ sodium chloride in water; their $\mathrm{pH}$ was adjusted to $7 \cdot 4$.

\section{ANALYTICAL PROCEDURES}

For GSH analysis, $1.0 \mathrm{ml}$ liver homogenate was mixed with $4.0 \mathrm{ml}$ ice cold $10 \%$ trichloroacetic acid in water. After 15 minutes the mixture was centrifuged at $3000 \mathrm{~g}$ for 20 minutes; GSH was determined colorimetrically with the Ellman reagent. ${ }^{5}$ Antimony was assayed by atomic absorption spectrometry using either a Zeeman graphite tube atomiser and a SpectrAA-30 spectrometer from Varian or a model AA-1275 Varian spectrometer coupled with a MHS-20 device (quartz tube for hydride determination) from Perkin-Elmer; with this procedure, methylantimony species, if present in the analysed biological medium, can be detected. ${ }^{6}$ In some experiments, samples $(1 \mathrm{~g}$ tissue or faeces, $10 \mathrm{ml}$ urine, or $0.1 \mathrm{ml}$ bile) were also wet ashed with concentrated $\mathrm{HNO}_{3}$ in the presence of $100 \mu \mathrm{g} \mathrm{Ni}$ or dry ashed with $\mathrm{Mg}\left(\mathrm{NO}_{3}\right)_{2}$ in a $\mathrm{MgO}$ matrix ${ }^{7}$ before determination of $\mathrm{Sb}$.

Identification of specific Sb compounds was also attempted by the ion exchange technique developed by $\mathrm{Tam}^{8}$ et al for methylated arsenic metabolites.

The separation of $\mathrm{Sb}$, reduced (GSH), and oxidised glutathione (GSSG) was performed by paper chromatography using a 40:10:50 mixture of $\mathrm{n}$-butanol:acetic acid:water; the detection of $\mathrm{Sb}$ was performed with a $0.5 \mathrm{M} \mathrm{AgNO}_{3}$ solution in $2.5 \%$ $\mathrm{NH}_{4} \mathrm{OH}$ and that of $\mathrm{GSH}$ and $\mathrm{GSSH}$, with $0.2 \%$ ninhydrin in butanol. Spots were cut and their content of $\mathrm{Sb}$ was measured by atomic absorption spectrometry after ashing.

Table 1 Urinary and faecal excretion of $S b$ in rats given a single intraperitoneal or intravenous dose of $\mathrm{SbCl}_{3}$

\begin{tabular}{|c|c|c|c|c|c|c|c|c|c|c|c|c|c|c|c|}
\hline \multirow{3}{*}{$\begin{array}{l}\text { Dose ( } \mu g \\
\text { Sb/kg) } \\
\text { and route§ }\end{array}$} & \multicolumn{15}{|c|}{ Antimony $(\mu g)$ at time intervals } \\
\hline & \multicolumn{3}{|l|}{$0-24 h$} & \multicolumn{3}{|c|}{$24-48 h$} & \multicolumn{3}{|c|}{$48-72 h$} & \multicolumn{3}{|c|}{$72-96 h$} & \multicolumn{3}{|l|}{$0-96 h$} \\
\hline & Urine & Faeces & Total & Urine & Faeces & Total & Urine & Faeces & Total & Urine & Faeces & Total & Urine & Faeces & Total $\stackrel{ }{\supset}$ \\
\hline 200 IP & $\begin{array}{l}4 \cdot 17^{\star} \\
0 \cdot 30 \dagger \\
8 \cdot 2 \ddagger\end{array}$ & $\begin{array}{c}15 \cdot 18 \\
0 \cdot 78 \\
30 \cdot 0\end{array}$ & $\begin{array}{c}19 \cdot 35 \\
0 \cdot 84 \\
38 \cdot 2\end{array}$ & $\begin{array}{l}0.51 \\
0.10 \\
1 \cdot 0\end{array}$ & $\begin{array}{l}4 \cdot 32 \\
0 \cdot 69 \\
8 \cdot 5\end{array}$ & $\begin{array}{l}4.83 \\
0 \cdot 72 \\
9 \cdot 5\end{array}$ & $\begin{array}{l}0.35 \\
0.03 \\
0.7\end{array}$ & $\begin{array}{l}0.23 \\
0.07 \\
0.4\end{array}$ & $\begin{array}{l}0.58 \\
0.08 \\
1 \cdot 1\end{array}$ & $\begin{array}{l}0.34 \\
0.05 \\
0.7\end{array}$ & $\begin{array}{l}0 \cdot 10 \\
0 \cdot 01 \\
0 \cdot 2\end{array}$ & $\begin{array}{l}0.44 \\
0.05 \\
0.9\end{array}$ & $\begin{array}{c}5.37 \\
0.32 \\
10.6\end{array}$ & $\begin{array}{r}19 \cdot 83 \\
1.04 \\
39 \cdot 1\end{array}$ & $\begin{array}{l}25 \cdot 2 \mathrm{Q} \\
1.1 \mathrm{~F} \\
49 \cdot 7 \mathrm{~N}\end{array}$ \\
\hline 400 IP & $\begin{array}{l}9 \cdot 43 \\
1 \cdot 23 \\
9 \cdot 0\end{array}$ & $\begin{array}{c}27 \cdot 51 \\
2 \cdot 86 \\
26 \cdot 2\end{array}$ & $\begin{array}{c}36.94 \\
3.11 \\
35.2\end{array}$ & $\begin{array}{l}1.57 \\
0.21 \\
1.5\end{array}$ & $\begin{array}{c}13 \cdot 20 \\
3.35 \\
12 \cdot 6\end{array}$ & $\begin{array}{c}14 \cdot 77 \\
3 \cdot 36 \\
14 \cdot 1\end{array}$ & $\begin{array}{l}0.60 \\
0.09 \\
0.6\end{array}$ & $\begin{array}{l}0.21 \\
0.02 \\
0.2\end{array}$ & $\begin{array}{l}0.81 \\
0.09 \\
0.8\end{array}$ & $\begin{array}{l}0.50 \\
0.03 \\
0.5\end{array}$ & $\begin{array}{l}0.22 \\
0.02 \\
0.2\end{array}$ & $\begin{array}{l}0.72 \\
0.04 \\
0.7\end{array}$ & $\begin{array}{c}12 \cdot 10 \\
1 \cdot 25 \\
11 \cdot 6\end{array}$ & $\begin{array}{c}41 \cdot 14 \\
4 \cdot 40 \\
39 \cdot 2\end{array}$ & טـ \\
\hline 800 IP & $\begin{array}{c}18.00 \\
1.91 \\
8.7\end{array}$ & $\begin{array}{c}75 \cdot 72 \\
4.08 \\
36 \cdot 7\end{array}$ & $\begin{array}{c}93.72 \\
4.50 \\
45.4\end{array}$ & $\begin{array}{l}3.35 \\
0.46 \\
1.6\end{array}$ & $\begin{array}{c}16.51 \\
1.91 \\
8.0\end{array}$ & $\begin{array}{c}19.86 \\
1.96 \\
9.6\end{array}$ & $\begin{array}{l}0.95 \\
0.10 \\
0.5\end{array}$ & $\begin{array}{l}0.41 \\
0.15 \\
0.2\end{array}$ & $\begin{array}{l}1 \cdot 36 \\
0 \cdot 18 \\
0 \cdot 7\end{array}$ & $\begin{array}{l}0.72 \\
0.02 \\
0.3\end{array}$ & $\begin{array}{l}0.52 \\
0.01 \\
0.3\end{array}$ & $\begin{array}{l}1.24 \\
0.02 \\
0.6\end{array}$ & $\begin{array}{c}23.02 \\
1.97 \\
11.1\end{array}$ & $\begin{array}{c}93 \cdot 16 \\
4 \cdot 51 \\
45 \cdot 2\end{array}$ & $\begin{array}{r}116.18 \text { र } \\
4.96 \mathrm{~b} \\
56.3 \frac{\mathrm{c}}{\mathrm{D}}\end{array}$ \\
\hline 800 IV & $\begin{array}{c}39 \cdot 61 \\
2 \cdot 19 \\
19 \cdot 2\end{array}$ & $\begin{array}{c}34.51 \\
8.53 \\
16.8\end{array}$ & $\begin{array}{c}74 \cdot 12 \\
8 \cdot 81 \\
35 \cdot 9\end{array}$ & $\begin{array}{l}5 \cdot 21 \\
0 \cdot 33 \\
2 \cdot 5\end{array}$ & $\begin{array}{c}10 \cdot 58 \\
0.80 \\
5 \cdot 1\end{array}$ & $\begin{array}{c}15 \cdot 79 \\
0.86 \\
7 \cdot 6\end{array}$ & $\begin{array}{l}1.30 \\
0.22 \\
0.6\end{array}$ & $\begin{array}{l}4 \cdot 62 \\
0 \cdot 33 \\
2 \cdot 2\end{array}$ & $\begin{array}{l}5 \cdot 92 \\
0 \cdot 40 \\
2 \cdot 8\end{array}$ & $\begin{array}{l}0.14 \\
0.02 \\
0.1\end{array}$ & $\begin{array}{l}1 \cdot 02 \\
0.22 \\
0.5\end{array}$ & $\begin{array}{l}1 \cdot 16 \\
0 \cdot 22 \\
0 \cdot 6\end{array}$ & $\begin{array}{c}46 \cdot 26 \\
2 \cdot 22 \\
22 \cdot 4\end{array}$ & $\begin{array}{c}50.73 \\
8.57 \\
24.6\end{array}$ & $\begin{array}{c}96.99^{\circ} \\
8.860 \\
46.78\end{array}$ \\
\hline
\end{tabular}




\section{Results and Discussion} EXPERIMENTAL STUDIES

To determine the main route of elimination of trivalent $\mathrm{Sb}$ the excretion of $\mathrm{Sb}$ in urine and faeces was followed up for four days after a single intravenous or intraperitoneal administration of $\mathrm{SbCl}_{3}$ to rats. Table 1 shows the results.

Whatever the route of administration and the dose, around 45 to $55 \%$ of the amount of Sb administered was excreted within four days, most being eliminated during the first day. After intravenous administration of $\mathrm{Sb}$ about the same percentage of the administered dose was excreted in the urine and faeces whereas after intraperitoneal administration, about four times more $\mathrm{Sb}$ was excreted in the faeces than in the urine.

These results suggest that $\mathrm{Sb}$ is partly excreted through the bile. To confirm this, the bile of animals $(\mathrm{n}=5)$ given an intravenous dose of $800 \mu \mathrm{g} / \mathrm{kg} \mathrm{SbCl}$ was collected for seven hours and its content of $\mathrm{Sb}$ determined. During this time, the biliary flow ranged from 0.8 to $0.5 \mathrm{ml} / \mathrm{h}$ and about $10 \%$ (range $6-15 \%$ ) of the amount of $\mathrm{Sb}$ administered was recovered in the bile.

Animal experiments have shown that several metal ions such as arsenic, cadmium, copper, mercury, silver, and zinc can be excreted in the bile, probably with GSH as a carrier molecule. We have therefore attempted to assess whether GSH also plays a part in the biliary excretion of $\mathrm{Sb}$. Before the administration of $\mathrm{Sb}$, rats were treated with either BSO to depress the hepatic GSH content or with BHT to increase its concentration. At the time of killing ( 48 hours after administration of $\mathrm{Sb}$ ) the average $\mathrm{GSH}$ concentration in liver was $66 \%$ (BSO) and $120 \%$ (BHT) of that in control animals.

Whereas GSH depletion before $\mathrm{Sb}$ exposure decreased $\mathrm{Sb}$ faecal excretion and increased its urinary excretion, increased GSH concentrations in liver had an opposite effect (table 2). The results show the important role of hepatic GSH in the biliary excretion of $\mathrm{Sb}$.

It has been shown previously that metals secreted into the bile may undergo an enterohepatic cycle. We have assessed whether such a phenomenon may also occur with $\mathrm{Sb}$. The bile of an animal pretreated with $\mathrm{SbCl}_{3}(800 \mu \mathrm{g} \mathrm{Sb} / \mathrm{kg})$ and containing $70 \mu \mathrm{g} \mathrm{Sb} / \mathrm{ml}$ was administered intraduodenally at a dose of $1 \mathrm{ml} / \mathrm{kg}$ to control anaesthesised rats $(n=3)$ whose bile ducts were cannulated for bile collection. The animals were killed five hours after treatment. The bile collected during this period contained a mean value of 22.4 (SE $1.3) \%$ of the administered Sb dose whereas the liver had accumulated $10 \cdot 7(2 \cdot 0)$ and the kidney $2 \cdot 0(0.3) \%$ of the dose. These results indicate that $\mathrm{Sb}$ undergoes an enterohepatic cycle.

Attempts were made to characterise the nature of the metabolites in bile and in urine. Paper chromatography of bile collected from animals pretreated with $\mathrm{Sb}\left(\mathrm{SbCl}_{3} ; 800 \mu \mathrm{g} / \mathrm{kg}\right.$ intraperitoneally) showed that $\mathrm{Sb}$ can be detected at a spot with an $\mathrm{Rf}$ value similar to that of GS-Sb-GS complex (results not shown). Further characterisation of the metal complex, however, is necessary to conclude that $\mathrm{GSH}$ is the only $\mathrm{Sb}$ chelating thiol present in bile. Despite the fact that in vitro $\mathrm{Sb}\left(10^{-5} \mathrm{M}\right)$ can completely inhibit the methylation of trivalent arsenic by rat liver cytosol ${ }^{9}$ (results not shown) all the attempts (hydride formation, ion exchange chromatography, various mineralisation procedures) to detect any organic form of $\mathrm{Sb}$ failed. It can therefore be concluded that contrary to inorganic arsenic, $\mathrm{Sb}$ is not methylated in the organism and is excreted in the inorganic form in urine.

\section{HUMAN OBSERVATIONS}

\section{Acute intoxication}

The concentration of $\mathrm{Sb}$ in whole blood, urine, bile, and gastric fluid from an adult woman who had attempted to commit suicide by ingestion of an unknown amount of $\mathrm{Sb}_{2} \mathrm{~S}_{3}$ was followed up for 160 hours.

Figure 1 illustrates the evolution of the concentration of $\mathrm{Sb}$ in the various biological media analysed. In bile and in gastric fluid, Sb was no longer detectable 100 hours after the ingestion, whereas in blood and in urine, the concentration was still above the normal value (blood $>0 \cdot 1 \mu \mathrm{g} / 100 \mathrm{ml}$; urine $>1 \mu \mathrm{g} / \mathrm{g}$ creatinine) one week after the ingestion. The amount of $\mathrm{Sb}$ recovered from urine was identical whether the urine

Table 2 Influence of BSO or BHT pretreatment on the mean urinary and faecal excretion of Sb in rats $(n=6)$ given a single intraperitoneal dose of $\mathrm{SbCl}_{3}$

\begin{tabular}{|c|c|c|c|c|c|c|}
\hline \multirow[b]{2}{*}{$\begin{array}{l}\text { Dose }(\mu g \mathrm{Sb} / \mathrm{kg}) \\
(+ \text { pretreatment })\end{array}$} & \multicolumn{6}{|c|}{ Antimony ( $\mu g(S E))$ at time intervals: } \\
\hline & $\begin{array}{l}0-24 h \\
\text { Urine }\end{array}$ & $24-48 h$ & $\begin{array}{l}0-24 h \\
\text { Faeces }\end{array}$ & $24-48 h$ & $\begin{array}{l}0-24 h \\
\text { Urine }+ \text { faeces }\end{array}$ & $24-48 h$ \\
\hline $\begin{array}{l}800 \mathrm{IP} \\
800 \mathrm{IP}(+\mathrm{BSO}) \\
200 \mathrm{IP} \\
200 \mathrm{IP}(+\mathrm{BHT})\end{array}$ & $\begin{array}{c}24.5(2.6) \\
64 \cdot 9^{\star}(8.6) \\
4 \cdot 2(0.8) \\
1.4^{\star}(0.2)\end{array}$ & $\begin{array}{l}3.6(0.5) \\
8.6^{\star}(1.7) \\
0.5(0.05) \\
0.4 \quad(0.05)\end{array}$ & $\begin{array}{c}54.4(11 \cdot 6) \\
5.9^{\star}(1 \cdot 8) \\
16 \cdot 2(2 \cdot 1) \\
29 \cdot 1^{\star}(5 \cdot 5)\end{array}$ & $\begin{array}{c}13.7(2.9) \\
4.77^{\star}(1.0) \\
4.1 \quad(1.0) \\
5.1 \quad(0.6)\end{array}$ & $\begin{array}{l}79.0(10.6) \\
70.9(9.2) \\
20.4(2.8) \\
30.5^{\star}(2 \cdot 2)\end{array}$ & $\begin{array}{r}17 \cdot 3(3 \cdot 1) \\
13 \cdot 3(3 \cdot 5) \\
4 \cdot 6(0 \cdot 9) \\
5 \cdot 4(0 \cdot 7)\end{array}$ \\
\hline
\end{tabular}

*Statistically different from control values ( $p<0.05$; Student's $t$ test). 

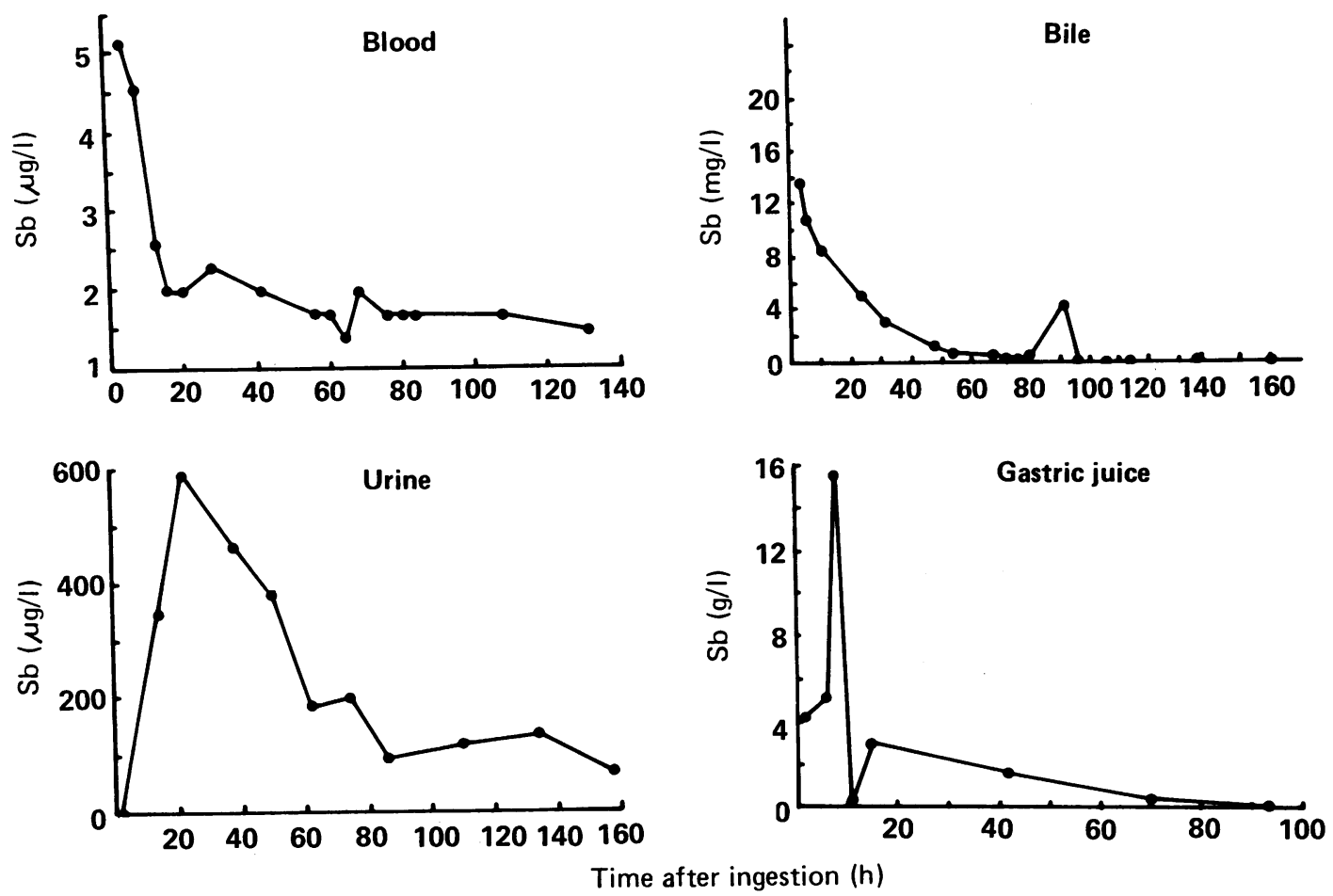

Figure 1 Evolution of Sb concentration in blood, bile, urine, and gastric juice in a woman after voluntary ingestion of an unknown amount of $\mathrm{Sb}_{2} \mathrm{~S}_{3}$.

Table 3 Antimony concentration in air and in the urine of workers

\begin{tabular}{|c|c|c|c|c|}
\hline \multirow[b]{3}{*}{ Workplace } & \multirow[b]{3}{*}{$\begin{array}{l}\text { No of } \\
\text { measure- } \\
\text { ments }\end{array}$} & \multicolumn{3}{|c|}{ Antimony concentration } \\
\hline & & \multirow[b]{2}{*}{ In air $\left(\mu g / m^{3}\right)$} & \multicolumn{2}{|c|}{ In urine ( $\mu \mathrm{g} / \mathrm{g}$ creatinine) } \\
\hline & & & $\begin{array}{l}\text { Before } \\
\text { the shift }\end{array}$ & $\begin{array}{l}\text { At the end of } \\
\text { the shift }\end{array}$ \\
\hline Wet process & 26 & $\begin{array}{l}86(78)^{\star} \\
(68,1.94) \dagger\end{array}$ & $\begin{array}{c}8 \cdot 2(3 \cdot 9) \\
(7 \cdot 5,1 \cdot 51)\end{array}$ & $\begin{array}{c}12.3(5 \cdot 0) \\
(11 \cdot 3,1.56)\end{array}$ \\
\hline Dry process & 14 & $\begin{array}{l}927(985) \\
(594,2 \cdot 62)\end{array}$ & $\begin{array}{l}58 \cdot 4(62 \cdot 5) \\
(40 \cdot 4,2 \cdot 34)\end{array}$ & $\begin{array}{l}110(76) \\
(91,1.90)\end{array}$ \\
\hline
\end{tabular}

^Arithmetic mean (standard deviation).

†(Antilog of geometric mean, geometric standard deviation).

was analysed without pretreatment or was wet $\left(\mathrm{HNO}_{3}\right)$ or dry $\left(\mathrm{MgO}+\mathrm{Mg}\left(\mathrm{NO}_{3}\right)_{2}\right)$ ashed before analysis. This finding agrees with the experimental results suggesting that $\mathrm{Sb}$ is not methylated in vivo.

\section{Occupational exposure}

Twenty two workers employed in the production of two pentavalent $\mathrm{Sb}$ compounds (antimony pentoxide and sodium antimoniate) were equipped with a personal air sampler during one or two whole shifts, for monitoring total airborne concentration of $\mathrm{Sb}$ in

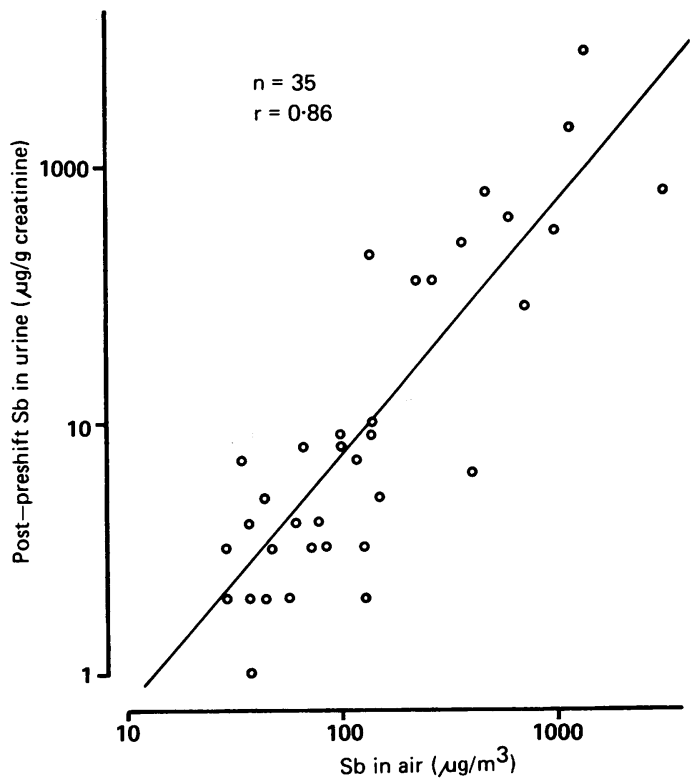

Figure 2 Relation between the time weighted average concentration of $S b$ in air (total dust) collected by means of personal samplers and the difference between $S b$

concentrations in postshift and preshift urine samples. 
their breathing zone. A urine sample was collected at the beginning and at the end of the workday for the determination of its $\mathrm{Sb}$ and creatinine content. The monitoring took place during the second part of a work week. One series $(n=26)$ of measurements was made while the workers were handling a solution or a wet paste containing $\mathrm{Sb}$ (wet process) and a further series $(n=14)$ was performed while the workers were grinding, sieving, and packaging dry Sb products (dry process). As expected, the average environmental exposure to $\mathrm{Sb}$ was different during the operations and this was reflected in the urinary concentrations of $\mathrm{Sb}$ at the end of the shift (table 3).

The correlation between the airborne concentrations of $\mathrm{Sb}$ (log value) and the concentrations (log value) in postshift urine samples was highly significant $(r=0.83, p<0.0001)$. The correlation was better $(r=0.86, p<0.0001)$ if the increase in $\mathrm{Sb}$ concentration in urine during the shift was considered rather than the postshift urine concentration (figure 2). The regression equation suggests that, on average, an airborne concentration of $\mathrm{Sb}$ in the order of the current threshold limit value $\left(500 \mu \mathrm{g} / \mathrm{m}^{3}\right)$ leads to an increase in urinary Sb concentration of $35 \mu \mathrm{g}$ $\mathrm{Sb} / \mathrm{g}$ creatinine during the shift.

\section{Conclusion}

Contrary to inorganic arsenic, inorganic $\mathrm{Sb}$ is not methylated in vivo in rats and in man. It is mainly excreted in bile and in urine. In bile the metal is combined with glutathione, the hepatic concentration of which may modulate the relative importance of these excretion routes. The Sb excreted in bile is partly reabsorbed in the intestine.
A preliminary study on workers exposed to pentavalent $\mathrm{Sb}$ suggests that determination of its concentration in urine may be used to assess the intensity of recent exposure.

A biological limit value of $35 \mu \mathrm{g} \mathrm{Sb} / \mathrm{g}$ creatinine between the start and the end of the shift is tentatively proposed.

Request for reprints to: $\mathrm{R}$ Lauwerys, Industrial Toxicology and Occupational Medicine Unit, Catholic University of Louvain, Clos Chapelleaux-Champs 30.54, B-1200 Brussels, Belgium.

1 Elinder CG, Friberg L. Antimony. In: Friberg L, Nordberg GF, Vouk VB, eds. Handbook on the toxicology of metals. Vol II. Amsterdam: Elsevier, 1986.

2 Norseth T, Martinsen I. Biological monitoring of antimony. In: Clarkson TW, Friberg L, Nordberg GF, Sager PR, eds. Biological monitoring of toxic metals. New York: Plenum Press, 1988.

3 Lüdersdorf R, Fuches A, Mayer P, Skulsuksai G, Schäcke G. Biological assessment of exposure to antimony and lead in the glass-producing industry. Int Arch Occup Environ Health 1987;59:469-74

4 Waynforth HB. Experimental and surgical techniques in the rat. London: Academic Press, 1980.

5 Ellman GL. Tissue sulphydryl groups. Arch Biochem 1959; 82:70-7.

6 Andreae MO, Asmodé JF, Foster P, Van't dack L. Determination of antimony III, antimony (IV), and methylantimony species in natural waters by atomic absorption spectrometry with hydride generation. Anal Chem 1981;53:1766-71.

7 Buchet JP, Lauwerys R, Roels $H$. Comparison of several methods for the determination of arsenic compounds in water and in urine. Int Arch Occup Environ Health 1980;46:11-29.

8 Tam GK, Charbonneau SM, Lacroix G, Bryce F. Separation of arsenic metabolites in dog plasma and urine following intravenous injection of ${ }^{74} \mathrm{As}$. Anal Biochem 1978;86:505-11.

9 Buchet JP, Lauwerys R. Study of inorganic arsenic methylation by rat liver in vitro: relevance for the interpretation of observations in man. Arch Toxicol 1985;57:125-9.

Accepted 6 August 1990. 